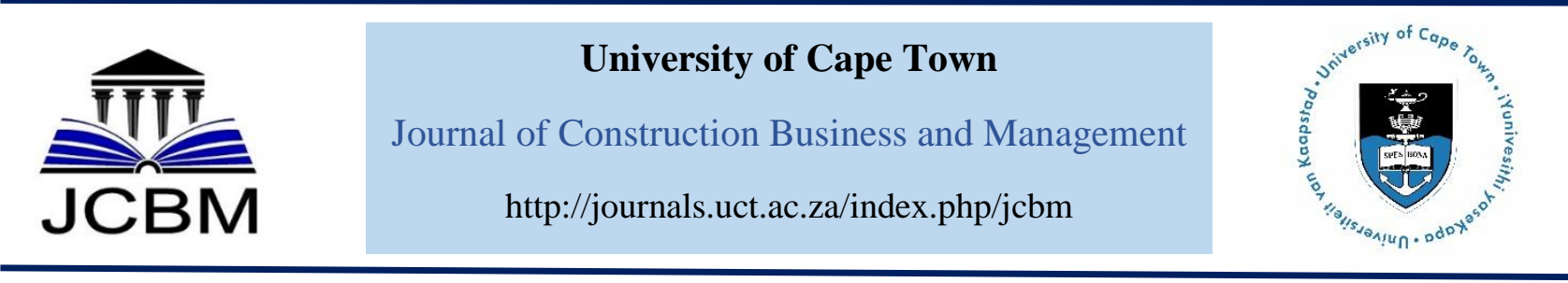

\title{
Organisational Commitment of Construction Skilled Workers in Selected Construction Firms in Nigeria
}

\author{
D.O. Aghimien ${ }^{1}$, O. A. Awodele ${ }^{2}$, and C.S. Maipompo ${ }^{3}$ \\ ${ }^{1}$ Sustainable Human Settlement and Construction Research Centre, Faculty of Engineering and the Built Environment, \\ University of Johannesburg, South Africa. \\ ${ }^{2 \& 3}$ Department of Quantity Surveying, Federal University of Technology, Akure, Ondo State, Nigeria.
}

Received 9 December 2017; received in revised form 1 February 2018, 22 March 2018 and 16 September 2018; accepted 20 September 2018.

https://doi.org/10.15641/jcbm.3.1.2019.481

\begin{abstract}
Skilled construction workers are crucial to the successful delivery of construction projects. However, there have been reports of their shortage within the Nigerian construction industry. Ensuring commitment of the few available ones to their organisation is important as this is bound to influence the service delivery of these organisations. This paper presents the result of the assessment of the organisational commitment of skilled construction workers in Abuja, Nigeria. A quantitative survey design was adopted, and data were gathered from selected skilled construction workers in 31 construction companies registered with Nigeria's Federation of Construction Industry. Organisational Commitment Scale was adopted in assessing the commitment of these set of workers, and data were harnessed through the use of a questionnaire. Percentage, mean item score and Kruskal-Wallis H-Test were used in analysing the data gathered. Cronbach Alpha test was also conducted to test the reliability of the research instrument. The study revealed that the common type of commitment exhibited by skilled construction workers is the continuance commitment. Factors such as getting feedback from supervisors, payment received being equal to work done, and the availability of opportunities to grow, play a major role in the commitment type being exhibited. The practical implication of this result is that construction companies within the country need to improve in the aspect of human resource management to attain better commitment and at the same time improve their productivity. It is believed that the findings of this study will assist construction organisations in adopting the right method that will help enhance the organisational commitment of their skilled workers.
\end{abstract}

Keywords: Construction workers, Nigeria, Organisational commitment, Skilled workers, Workers satisfaction.

\section{Introduction}

In the delivery of construction projects, there is the need for labour (skilled and unskilled). Construction firms rely heavily on these set of workers in order to carry out their activities. According to Olofinji (2016), skilled construction workers play an important role in the survival and growth of the construction industry since the practical completion of projects depend largely on them. Despite the obvious importance of these set of workers, the shortage of same has been evident in the construction industry of most developing countries around the world. It is believed that the construction industry appears not to be appealing to youths. Young people tend to pursue college degrees more, with lesser desire to take up blue- collar jobs (Tucker et al., 1999). Reason for this, among other factors, can be the poor organisational investment and lack of promotion avenues within most construction companies (Carley et al., 2003). In Nigeria, although the country as a whole is blessed with a skilled workforce, the situtation within its construction industry is ironic. While the Nigerian construction industry (NCI) is believed to be one of the highest employers of labour, the industry is still faced with problems of shortage in technically skilled workers (Bilau et al., 2015).

Commitment which according to Nehmeh (2009), is as an attachment or loyalty within an organisation, can go both ways. This can be a worker's commitment to the organisation or the organisation's commitment to its workers. While it is assumed that workers need to show

\footnotetext{
${ }^{1}$ Corresponding Author.

Email address: aghimiendouglas@yahoo.com
} 
some sense of attachment or loyalty to their organisation, they also need reassurance that their jobs are secure. Although this present study focused on worker's commitment to their organisation, issues surrounding the organisation's commitment to their workers can be seen in most human resource management (HRM) studies. The choice of basing this study on workers commitment to their organisation is premised on the fact that skilled workers are important to the successful delivery of construction projects, and their shortage is evident within the NCI. Thus, it is important to ascertain the commitment of the available ones to their organisations. The commitment of a worker, according to Miller (2003), can be described as that point where such worker identifies with the goals of his or her organisation and strives to maintain affiliation with such organisation. Therefore, skilled workers commitment in the context of this study is the state or level of identification of these set of workers with their respective organisations and their desire to continue in that organisation.

Bhatti and Qureshi (2007) submitted that the major issue of most organisations is the implementation strategies that could help the development of their human resources. In construction, Ibrahim et al., (2010) noted that the key problem in the achievement of construction demands is related to human resources within the industry. This shows that there is the need to adequately ascertain the factors that influence the desire of construction workers to stay or leave a particular organisation, in order to effectively manage the available workforce within the organisation and achieve desired commitment and optimum worker's productivity.

This study identifies with the fact that various research has been conducted on organisational commitment of workers in most sectors and even the construction industry (Abiola-Falemu, 2013; Ashraf et al., 2012; Gangai and Agrawal, 2015; Girth et al., 2013; Haq et al., 2014; Luchak, et al., 2008; Norizan, 2012; Oyewobi et al., 2012; Salim et al., 2007). However, not much has surfaced regarding the commitment of skilled construction workers whose impact in successful project delivery is crucial and which unfortunately is becoming scarce in the NCI. It is in light of this that this study assessed the commitment of skilled construction workers in selected construction firms in Nigeria, through the identification of the type of commitment exhibited by this set of workers, and the factors influencing their commitment. This was done towards providing possible recommendations that will improve their commitment and by so doing improving the construction firm's project delivery.

\section{Literature Review}

\subsection{Skilled Construction Workers in the Construction Industry}

The impact of the availability of skilled construction workers on construction projects, coupled with the expectation from construction contractors to deliver projects of desired quality, cost and on schedule, has been sufficiently reported in literature (Institute of Management and Administration [IOMA] 2005; Medugu et al., 2011; Olomolaiye and Ogunlana, 1989; Ugheru, 2006). Studies have also shown that skilled construction workers contribute greatly to the successful delivery of the end products of the construction industry (Medugu et al., 2011). According to Bustani (2000), for the industry to be effective in the delivery of its services, the quality and availability of its skilled workforce are important. The insufficiency of technically qualified personnel in the face of increased demand has led to a situation where the big contractors are considering investing in training and development (T\&D) of their workforce. This T\&D can be seen as a way of garnering more workers' commitment to their organisation (Owoyemi et al., 2011). In an industry where the shortage of skilled workers has been identified as a challenge (Bilau et al., 2015), the commitment of the available ones to their organisation is crucial.

\subsection{Organisational Commitment}

Often commitment is described as that force of cohesion between an individual and some course of action relevant to the attainment of one or more goals (Cohen, 2003). Organisational commitment can be the commitment from an organisation to the employee or commitment from the employee to the organisation. This study, however, focused on the latter. Miller (2003) opined that organisational commitment could be seen as "a state in which an employee identifies with a particular organisation and its goal and wishes to maintain membership in the organisation". Arnold et al. (2005) further stated that organisational commitment is that relative strength an individual exhibits when they indentify with and are involved in, the activities of an organistion. Thus, when an employee is committed to an organisation, there is every tendency that such employee will not want to leave. Hence, there is a sense of responsibility and attachment to an organisation by a committed employee. The most popular method of ascertaining the type of commitment of employees is the Meyer et al. (1993) organisational commitment scale (OCS). This approach is the most widely accepted conceptualisation of organisational commitment and has been adopted for over 20 years (Cohen, 2003). It sees commitment from three facets. One is that commitment can be affective in nature. Also, commitment can be continuance or normative.

\subsubsection{Types of Commitment}

Cohen (2003) viewed affective commitment as a positive affection towards an organisation. This positive affection is reflected in the employee's desire to see the organisation succeed. Affective commitment can also be seen as the emotional attachment an employee has to his/her organisation. It is believed that employees that exhibit this kind of commitment remain in their organisation out of their own volition not just as a 'means to an end' (Allen and Meyer, 1997). This form of commitment is based solely on individual's desire. For continuance commitment, Meyer et al. (1993) describe this as an individual's knowledge of the price they will have to pay for leaving an organisation. People who exhibit this commitment type remain in their organisation not because they want to, but because they need to. They find it difficult to leave their organisation due to the fear of the unknown or having few or no other option (Nagar, 2012). Normative commitment according to Antilla 
(2014) is the feeling of obligation to stay within an organisation. As a result of this feeling, an employee will remain with an oragnisation because he/she feels they obligated to do so. It is believed that the experience of workers within and outside the organisation plays a vital role in the exhibition of this type of commitment. This means that normative commitment of an employee emanates from both the relationship they have within the organisation and that which they experience within their immediate family and society (Allen and Meyer 1990; Markovits et al., 2013).

\subsubsection{Factors Influencing Skilled Workers Commitment}

Several factors influence the type of commitment exhibited by an employee. Haq et al., (2014) opined that factors such as job conditions, supervisor's support, rewards, work-family support, and career growth opportunities affect the commitment of employees to an organisation. This implies that if an organisation wants to have a higher commitment from its workforce, these outlined factors should be improved and in effect, employees, in turn, will exhibit such behaviours as beneficial to the organisation. Bhavna and Swati (2012) outlined some factors that influence employee's commitment. These factors are "the quality of working relationships, workplace leadership, having a say, clear values, being safe, the built environment, recruitment, pay, and conditions, getting feedback, autonomy and uniqueness, a sense of ownership and identity, learning, passion, having fun, and community connections". Antilla (2014) assessed the components of organisational commitment and concluded that the significant factors affecting organisational commitment could be company related factors, community-related factors, and work characteristics factors. Alsiewi and Agil (2014) examined job satisfaction influence on affective commitment and observed that most of the job satisfaction variables which include; job security, pay, and benefits, feelings of satisfaction towards teaching staff and principals, growth and development opportunities and relevance and meaning of job have a significant relationship with affective commitment.

Adeyemo and Aremu (1999) analysed the effects of some multiple predictors on satisfaction and commitment of workers. The study concluded that the variety in skills and ambiguity in the role of workers are best determinantes of satisfaction, while the kind of leadership within the organisation coupled with the organisation's age are best determinantes of commitment. Adeyemo (2000) observed that there exist a positive relationship between education and organisational commitment. This was rather in contrast to earlier findings of Ellemer et al. (1998) which revealed that background variables such as gender, level of education, or team size have no significant relationship to any of the three forms of commitment an employee can exhibit. Similarly, Irving et al. (1997) found that age has nothing to do with the kind of commitment an employee will have to his/her organisation. This submission, however, contradicts Meyer and Allen (1984) submission that age influences commitment. On the issue of gender, Mathieu and Zajac (1990) reported its relationship to organisational commitment. This was further confirmed by Irving et al., (1997)'s findings which revealed that out of a group of people sampled, men had a higher level of commitment than the women.

\section{Research Methodology}

This study assessed the commitment of skilled construction workers in selected construction firms in Nigeria, using Abuja as the study area. The choice of this area is premised on the fact that Abuja is one of the metropolitan cities in Nigeria and it is also the administrative centre of the country. The area has lots of construction projects being executed on a daily basis, and as such has attracted, many construction organisations with most of them having their head office or branches there. A survey approach was adopted, and quantitative data were gathered from skilled construction workers in 31 construction firms registered with Nigeria's Federation of Construction Industry which is the largest body of construction contractors in the country (Aje et al., 2015). The choice of a quantitative questionnaire survey was based on the fact that the study hoped to solicit responses from a different set of skilled workers within these identified organisations. As a result, a qualitative study through an interview or other approaches would have been time-consuming and almost practically impossible to achieve. Tan (2011) described the questionnaire survey as a simple survey approach which can cover a wider range of audience within a short period. Also, Ackroyd and Hughes (1981) described the questionnaire as a tool which can achieve quantifiability and objectiveness in research, hence its adoption in this study.

The questionnaire used was designed in two parts. Part A dwelt on the background information of respondents, while Part B dwelt on the objective of the study. The objective one which was to determine the type of commitment exhibit by skilled construction workers in the study area was assessed using Meyer et al. (1993)'s OCS. Abiola-Falemu (2013) and Jena (2015) adopted a similar approach in determining the commitment of workers in Nigeria and India. The OCS employs the use of specific questions relating to the three major commitment types and respondents were asked to rate these questions on a 5-point Likert scale. The second objective aimed at identifying the factors influencing the commitment of these set of workers was also assessed on a 5-point Likert scale based on their level of significance, with 5 being very high, 4 being high, 3 being average, 2 being low and 1 being very low. While some of the respondents were able to fill the administered questionnaire themselves, others could not as a result of their lack of formal education. In this case, the researcher personally read the questions, and the respondents gave their answers which were adequately filled on their behalf.

A total of 93 questionnaires were distributed (3 each for the identified 31 construction firm), with 71 retrieved. This shows a response rate of $76 \%$, and this is far above the usual response rate of $20-30 \%$ for questionnaire surveys in construction management studies, as suggested by Akintoye (2000) and Moser and Kalton (1999). The reliability of the instrument used was tested using Cronbach's alpha test. The normal range of Cronbach 
alpha value is between 0.0 and +1.0 , and the higher the value, the higher the degree of internal consistency. The alpha values of 0.717 and 0.911 were derived for the type of commitment, and factors influencing the type of commitment of skilled workers respectively. This result shows that the questionnaire use is reliable since the alpha values are closer to 1.0. Data analysis was done using frequency and percentage in analysing the background information of the respondents. Kruskal-Wallis H-test which is a non-parametric test used in testing the relationship in the view of three or more groups of respondents was employed in testing the relationship in the view of all the various types of skilled workers as regards their commitment types and the factors influencing the type of commitment they exhibit. Mean Item Score was further employed in ranking the various commitment types and factors based on the respondents' selection.

\section{Findings}

\subsection{Background Information}

The result in Table 1 shows the characteristics of the respondents sampled. From the table it is evident that skilled male workers dominate the assessed construction organisations. Most of these skilled workers fall within the age range of 31 to 40 with an average age of 32 years recorded. Concerning employment types, most skilled workers $(60.6 \%)$ work for their respective construction organisation on a contract basis, while some $(32.4 \%)$ are employed on a part-time basis. Only $5.6 \%$ are full- time workers for their respective organisations. This implies that construction organisations in the study area rarely employ permanent skilled workers; instead, they rely more on hiring workers on a temporary basis. More response was gathered from skilled workers involved in masonry (22.5\%), carpentry (19.7\%) and electrical works (12.7), most of whom do not have any formal education $(47.9 \%)$. However, $42.3 \%$ possess ordinary level $\left(\mathrm{O}^{\prime}\right.$ level), while $9.9 \%$ possess a national diploma. The highest years of working experience of the respondents fall between 6 to 10 years $(26.8 \%)$ and 16 to 20 years $(23.9 \%)$. On average, the respondents have 13 years of working experience, and an average of 4 years working with their present organisation. Based on the background information of the respondents, it is evident that most skilled workers sampled are matured in terms of age and working experience to give reasonable answers to the questions of the research.

Table 1: Background information of respondents

\begin{tabular}{llcc}
\hline Category & Classification & Frequency & Percentage \\
\hline \multirow{2}{*}{ Gender } & Male & 69 & 97.2 \\
& Female & 2 & 2.8 \\
\hline \multirow{3}{*}{ Age } & $18-30$ & 27 & 38.0 \\
& $31-40$ & 36 & 50.7 \\
& $41-60$ & 8 & 11.3 \\
\multirow{3}{*}{ Employment } & Full Time & 4 & 5.6 \\
Type & Part Time & 24 & 33.8 \\
& Contract & 43 & 60.6 \\
& Total & 71 & 100.0 \\
\hline
\end{tabular}

\begin{tabular}{llcc}
\hline & Masonry & 16 & 22.5 \\
& Carpentry & 14 & 19.7 \\
& Electrical & 9 & 12.7 \\
Area of & Metal-works & 7 & 9.9 \\
Specialization & Plumbing & 7 & 9.9 \\
& Tiling & 7 & 9.9 \\
& Painting & 6 & 8.5 \\
& Roofing & 5 & 7.0 \\
\hline \multirow{2}{*}{ Academic } & None & 34 & 47.9 \\
qualification & O'Level & 30 & 42.3 \\
& OND & 7 & 9.9 \\
\hline \multirow{4}{*}{ Years of } & $0-5$ & 8 & 11.3 \\
experience & $6-10$ & 19 & 26.8 \\
& $11-15$ & 14 & 19.7 \\
& Ab-20 & 17 & 23.9 \\
Years with the & $0-5$ & 13 & 18.3 \\
present & $6-10$ & 55 & 77.5 \\
organisation & Total & 16 & 22.5 \\
\hline Key: O'Level: & Ordinary Level Certificate; OND: Ordinary \\
National Diploma & & &
\end{tabular}

\subsection{Type of Commitment Exhibited by Skilled Construction Workers}

In assessing the type of commitment skilled workers exhibit, some commitment statements were identified from existing literature and respondents were asked to rate their level of agreement with these statements as they apply to them. These statements were asked in no particular order, and no heading was given in the questionnaire. This was done in a bid to avoid bias in the choice of respondents' response. However, Table 2 shows these commitment statements grouped under their respective commitment types during analysis. The result in Table 3 shows the different commitment types as rated by the respondents. Since these skilled workers have different employment types which include full-time, parttime and contract, it is believed that their type of commitment may vary. Based on this assumption, Kruskal-Wallis H-Test which is a non-parametric test was adopted to determine if there is a statistically significant difference in the response of the three different groups of respondents as regards these commitment variables. This test compares the mean value of the groups and converts the scores on the continuous variable to ranks, and determines the significant difference between the groups. It gives a chi-square value and a significant $p$-value. When the derived p-value is lower than the predetermined significance value of 0.05 , it means that there is a significant difference in the mean value of the groups (Pallant, 2005). In the case of this study, this implies that there is a significant difference in the view of respondents working on full-time, part-time, and contract basis. However, the reverse is the case if the derived p-value is higher than the predetermined significance value of 0.05 . The result revealed that under the affective commitment, six out of the eight assessed commitment variables have a mean score of above average of 3.0. The commitment variable of skilled workers having similar values with their organisation ranked top with a mean value of 3.51. Kruskal-Wallis test shows that there is no significant difference in the response of respondents from these different employment types, as a significant $p$-value of 
above 0.05 was derived for all assessed variables under this commitment group. This means that there is a unified view among the respondents as to how they exhibit this commitment type.

Under the continuance commitment, all the seven assessed commitment variables have a mean value of above average of 3.0. The most significant of these variables are; the fear of what might happen if they quit their job without having another one lined up and the feeling of having few options to consider before leaving their present organisation with a mean value of 3.82 and 3.63 respectively. Kruskal-Wallis test also revealed that there is no significant difference in the view of the three categories of respondents. A significant p-value of above 0.05 was derived for all commitment statement under this group. Hence there is a convergent view among the respondents as to them exhibiting this commitment type. For normative commitment, the result shows that all five assessed commitment variables have a mean value of above average of 3.0. However, the believe that a person must always be loyal to his/her organisation, was ranked top with a mean value of 3.58 , while "things were better in the days when people stayed with one organisation for most of their career life" was ranked as the least with a mean value of 3.00. Kruskal-Wallis test revealed that there is no significant difference in the view of the three categories of respondents as a p-value of above 0.05 was derived for all commitment statement under this group. Thus, the ranking of these variables can be relied upon as a convergent view was evident among the different group of respondents.

Table 2: Types of commitment assessed

\section{Types of Commitment}

\section{Affective}

My personal values with that of this organisation are similar Code

I enjoy discussing my organisation with people.

I will be happy to end my career in this organisation.

I am inspired to perform to my very best in this organisation.

I feel emotionally attached to this organisation.

The organisation makes me feel like I am part of a family.

I treat this organisation's problems as my own.

I have a strong sense of belonging here in this organisation.

\section{Continuance}

I am scared of quiting my job now as I do not have another one lined up.

My options are limited if I decide to leave this organisation.

I fear if I leave this organisation I will face scarcity of available alternatives

I feel leaving this organisation now will disrupt my life plans and activities.

Even if I wanted to leave this organisation right now, it will be difficult for me.

I fear that I might not get another organisation that will give me the same benefits I get from this organisation.

Right now, staying with this organisation is a matter of necessity.

\section{Normative}

I believe workers need to be loyal to their organisation.

Leaving this organisation wont be the right thing to do, even if I got a better offer

I was taught to believe in the value of remaining loyal to one organisation.

I think people these days move from company to company too often.

I believe it will be better if worker remains with one organisation for most of their career life.

Kruskal-Wallis H-Test also shows that on the overall, there is no significant difference in the commitment type exhibited by the different skilled construction workers employed on a full time, part time and contract basis, as a significant $p$-value of above 0.05 was derived for the three commitment types assessed (affective $=0.635$, continuance $=0.455$, normative $=0.970$ ). This result implies that the type of commitment being exhibited by skilled construction workers in the study area is not dependent on the basis on which they were employed. Looking at the group mean of each commitment type, it is evident that skilled construction workers mostly exhibit continuance commitment as it has the highest group mean of 3.45. This is followed by normative commitment with a group mean of 3.30 , while the least exhibited commitment type is affective commitment with a group mean of 3.11 .

Table 3: Types of commitment exhibited by skilled construction workers

\begin{tabular}{lcccc} 
& \multicolumn{2}{c}{ Overall } & \multicolumn{2}{c}{ Kruskal-Wallis } \\
\cline { 2 - 5 } Commitment & Mean & Rank & Chi-Sq. & Sig. \\
\hline Affective & & & & \\
Aff1 & 3.51 & 1 & 0.569 & 0.753 \\
Aff2 & 3.39 & 2 & 2.720 & 0.257 \\
Aff3 & 3.30 & 3 & 2.646 & 0.266 \\
Aff4 & 3.17 & 4 & 1.018 & 0.601 \\
Aff5 & 3.08 & 5 & 0.105 & 0.949
\end{tabular}




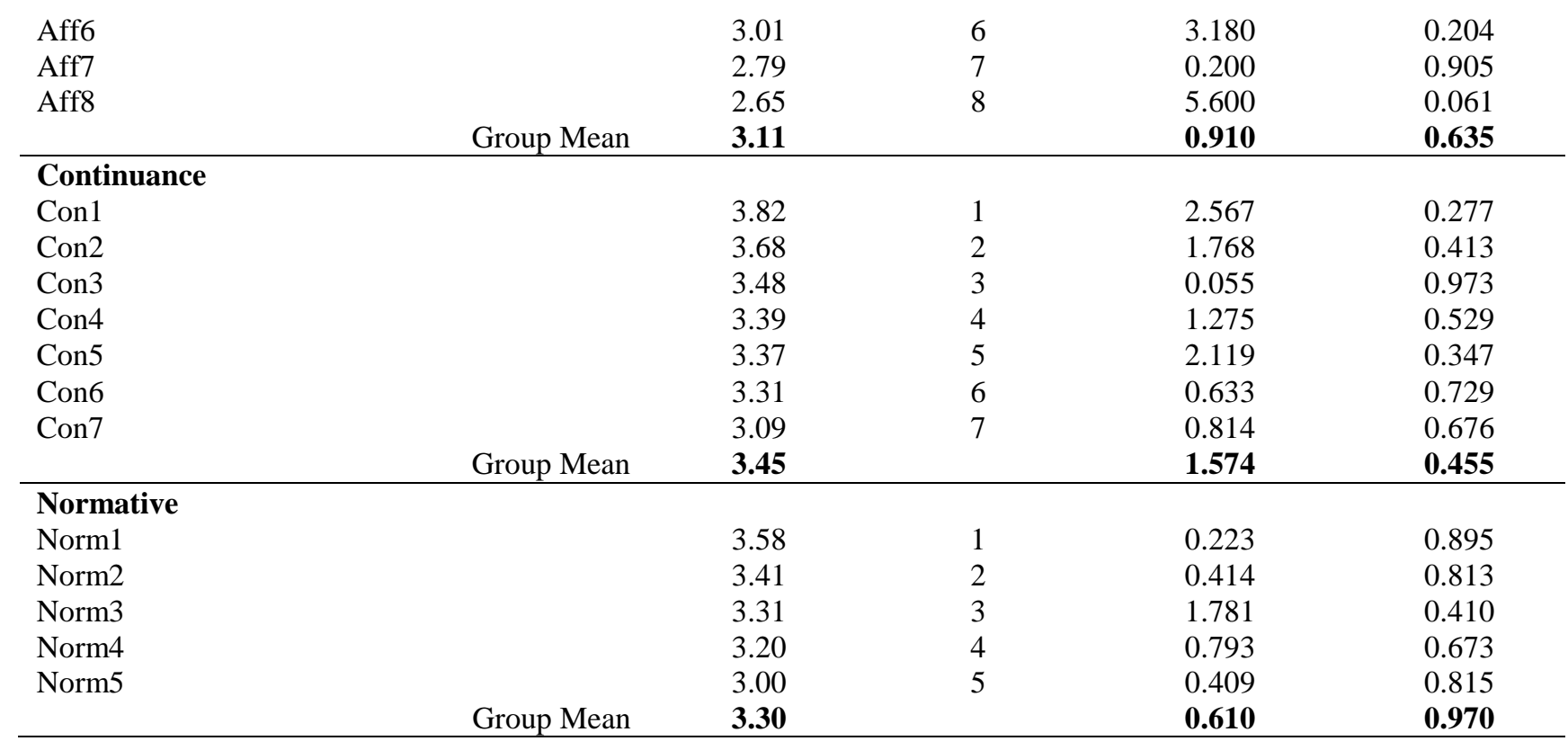

\subsection{Factors Influencing the Commitment of Skilled Construction Workers}

Result in Table 4 shows the rating of the identified factors influencing the commitment of skilled construction workers and their respective significant $p$-value derived from Kruskal-Wallis H-Test. From the table, it is evident that all the seventeen assessed factors have a mean value of above average of 3.0. This implies that to a considerable extent they all tend to influence the commitment of these set of workers. Chief of these factors are getting feedback from supervisors, payment received is equal to work done, and the availability of opportunities to grow, with a mean value of $3.92,3.66$ and 3.58 respectively. The least rank factor is the social relationship among workers with a mean value of 3.02. Kruskal-Wallis H-test also revealed that there is no statistically significant difference in the view of the different respondents with regards to the significance of the identified factors as a p-value of above 0.05 was derived. This result implies that irrespective of the type of employment, the factors influencing the commitment of skilled construction workers within the construction industry are the same. Thus, construction companies will do well to understand these factors and improve where necessary.

Table 4: Factors influencing the commitment of skilled construction workers

\begin{tabular}{lcccc}
\hline & \multicolumn{2}{c}{ Overall } & \multicolumn{2}{c}{ Kruskal-Wallis } \\
\cline { 2 - 5 } Factors & Mean & Rank & Chi.-Sq. & Sig. \\
\hline Getting feedback from supervisors & 3.92 & 1 & 1.578 & 0.454 \\
Payment received is equal to work done (fair wages) & 3.66 & 2 & 1.243 & 0.537 \\
Availability of opportunities to grow & 3.58 & 3 & 1.400 & 0.497 \\
Leadership support in job performance & 3.48 & 4 & 0.295 & 0.863 \\
Recognition of workers performance/efforts & 3.42 & 5 & 2.376 & 0.305 \\
Recognition of important holidays by the organisation & 3.41 & 6 & 1.852 & 0.396 \\
Availability of incentives such as bonus and payment of overtime & 3.41 & 6 & 1.243 & 0.537 \\
Leadership style that enhances job satisfaction & 3.37 & 8 & 1.491 & 0.475 \\
Company policy & 3.37 & 8 & 1.130 & 0.568 \\
Working environment & 3.34 & 10 & 0.898 & 0.638 \\
Having a sense of responsibility & 3.32 & 11 & 2.051 & 0.359 \\
Avenue for training and staff development & 3.24 & 12 & 0.859 & 0.651 \\
Having a balance between organisation values and personal values & 3.20 & 13 & 0.574 & 0.751 \\
The benefit of healthcare services & 3.18 & 14 & 2.117 & 0.347 \\
Good communication structure within the organisation & 3.14 & 15 & 3.044 & 0.218 \\
Opportunity to balance working life with family life & 3.09 & 16 & 1.023 & 0.600 \\
Social relationship among workers & 3.02 & 17 & 5.126 & 0.077 \\
\hline
\end{tabular}

\section{Discussions}

Findings revealed that the construction organisations in the study area rarely employ permanent skilled workers; instead, they rely more on hiring workers on a temporary basis. This might be associated with the fact that most of the construction companies in the country are the small and medium size (Ogbu, 2017) and they cannot finance projects independently before client's financial contribution (Odediran et al., 2012). This financial constraint is bound to affect their ability to keep skilled workers on a permanent basis, since they may not have 
many construction projects to handle. However, findings revealed that the type of organisational commitment exhibited by skilled construction workers is not dependent on their type of employment; either on a permanent, parttime or contract basis. This result follows the line of some past researches (Ellemer et al., 1998; Irving et al., 1997) that have discovered that background/demographic information such as gender, age, team size, level of education, do not have any significant relationship with the commitment type being exhibited. The major type of organisational commitment exhibited by skilled construction workers in the NCI is the continuance and normative type of commitment. Meyer et al. (1993) have stated that continuance commitment is an individual's awareness of the costs of leaving the organisation. According to Nagar (2012) workers with a high level of continuance commitment remain a member of the organisation because they need to. It has been established that when workers exhibit continuance commitment, they do not remain in their organisation because they are satisfied; rather they do it just because they need to, and they might have no other option (Gangai and Agrawal 2015; Lumley et al., 2011; Meyer et al., 1993).

This type of commitment being majorly exhibited by skilled construction workers within the study area is not the best as the organisation might not get the best from these set workers. According to Meyer and Allen (1997), the affective type of commitment motivates employees to higher levels of performance than continuance or normative commitment. Unfortunately, this commitment type is the least exhibited by these set of construction workers. This result is in contrast with the findings of Jena (2015) which revealed that workers in ferroalloy companies in Odisha, India exhibit more affective and normative commitment than continuance commitment. This disparity in result further emphasises the need for improvement in the NCI.

Findings of this study also revealed that the significant factors influencing the organisational commitment of skilled construction workers are getting feedback from supervisor, payment received isequal to work done, and availability of opportunities to grow. This result is in line with Bhavna and Swati (2012) submission that factors such as pay and conditions, and getting feedback, are crucial in achieving high employees' commitment. Martin and Root (2008) observed that workers generally value certain conditions of work, and when these conditions are met, they will be more satisfied and committed, with less intention to leave the organisation. One of these conditions is their payment. Lumley et al. (2011) submitted that workers pay is a significant determinant in explaining workers' overall commitment. Mathieu and Zajac (1990) have indicated that there is a positive relationship between pay and commitment of workers. According to Spector (1997), an unfair payment is bound to lead to demotivation of workers. Findings of this study also corroborate Haq et al., (2014) submission that factors such as growth opportunities affect the commitment of employees to an organisation. Oyewobi et al. (2012) discovered that Quantity surveyors in Nigeria are more committed to their jobs when there are adequate opportunities for advancement. This finding is not peculiar to this set of construction professionals alone, as this current study has been able to reveal that opportunities for growth is also important to skilled workers and it has a considerable influence on their commitment to their establishment.

\section{Conclusion}

This study set out to assess the organisational commitment of skilled construction workers in the NCI. Using a survey of selected skilled workers in Abuja, the study has been able to ascertain the type of commitment being exhibited by these set of workers, and the factors influencing their commitment. Based on the findings, the study concludes that the type of employment of skilled workers (full time, part-time or contract) has no significant relationship with their commitment type. Irrespective of the type of employment arrangement they have with their respective organisations, their commitment type is the same. As such, construction organisations within the country will do well by treating workers' commitment issues within their organisations in like manner.

The common type of commitment exhibited by skilled construction workers is the continuance commitment. The most significant factors influencing their commitment are; getting feedback from supervisors, payment received is equal to work done, and the availability of opportunities to grow. This, therefore, implies that construction companies within the country need to improve in the aspect of managing their human resources to attain better commitment and at the same time improve their productivity. This can be achieved by ensuring that giving feedback is a priority to site supervisors, as this has a huge tendency in influencing the commitment of skilled workers either negatively or positively. Also creating some job enrichment schemes and ensuring workers get fair wages is imperative if the commitment level of these workers is to change from being continuance to affective. At least the minimum standard obtainable for wages should be given to workers as this will help boost their moral to perform and increase their commitment to the organisation. Finally, the need to create opportunities for growth for these workers is essential. Occasional promotion of deserving workers, from ordinary site workers to site supervisors, can go a long way in increasing their commitment.

It is believed that the findings of this study will assist construction organisations within the country in doing appropriate planning and developing significant methods that will assist them in enhancing their organisational commitment of their skilled workers and by so doing increasing organisational performance and workers productivity. However, the major limitation of this study lies in the fact that the study was limited to the commitment of skilled construction workers in construction firms in Abuja, Nigeria. The findings can therefore not be generalised to other parts of the country, as situations and organisation policies might differ between regions of the country. Therefore, further studies can be conducted by appraising the commitment of skilled construction workers in construction firms in other areas or regions within the country in order to compare results. Also, more work can be done by assessing the effect of 
the commitment type exhibited by skilled construction workers, on their job performance.

\section{References}

Abiola-Falemu, J. O. (2013). Organisational culture, job satisfaction and commitment of Lagos-based construction workers, IOSR Journal of Business and Management, 13(6), 108-120

Ackroyd, S. and Hughes, J.A. (1981), Data Collection in Context, Longman: London, UK.

Adeyemo, D. A. and Aremu, A.O. (1999). Career commitment among secondary school teachers in Oyo state, Nigeria. The Role of biographical mediators. Nigerian Journal of Applied Psychology, 5 (2), 184-194.

Adeyemo, D.A. (2000). Job involvement, career commitment, organisational commitment and job satisfaction of the Nigerian police. A multiple regression analysis. Journal of Advanced Studies in Educational Management 5(6), 35-41.

Aje, I.O., Makanjuola, S.A and Olatunji, O.A (2015). Assessment of Factors Affecting Bid-No-Bid Decision of Construction Contractors in Nigeria. In: Ogunsemi, D.R., Awodele, O.A and Oke, A.E. (Eds). Proceedings of the 2nd Nigerian Institute of Quantity Surveyors Research Conference. Federal University of Technology, Akure 529-536

Akintoye, A., (2000). Analysis of factors influencing project cost estimating practice. Construction Management and Economics, 18 (1), 77-89.

Allen, N. J., and Meyer, J. P. (1997). Affective, continuance, and normative commitment to the organisation: An examination of construct validity. Journal of Vocational Behaviour, 49, 252-276

Allen, N., and Meyer, J. (1990) Organisational socialization tactics: a longitudinal analysis of links to newcomers' commitment and role orientation. The Academy of Management Journal, 33(4), 847-858.

Alsiewi, A. M. and Agil, S. (2014). Factors that influence affective commitment to teaching in Libya. IOSR-Journal of Business and Management, 16(2), 3746.

Anttila, E. (2014). Components of organisational commitment - A case study consisting of managers from Finnish industrial company master's thesis, School of Education, University of Tampere

Arnold, J. Silvester, J. Cooper, C.L., Robertson, I.T., and Patterson, F.M (2005). Work psychology: understanding human behaviors in the workplace, 4th edition, Prentice Hall/Financial Times.

Ashraf, Z., Jaffri, A. M, Sharif, M. T., and Khan, M. A (2012), Increasing employee organisational commitment by correlating goal setting, employee engagement and optimism at workplace, European Journal of Business and Management, 4 (2), 71-77

Bhatti, K. K and Qureshi, T. M. (2007). Impact of Employee participation on Job Satisfaction, Employee Commitment and Employee Productivity. International Review of Business Research Papers, 3(2), 54 - 68

Bhavna, A. and Swati, G., (2012) Maximum Success: Become an Employer of Choice, KKIMRC IJRHR, 1(2), $1-6$
Bilau, A. A., Ajagbe, M. A., Kigbu, H. H, and Sholanke, A. B. (2015). Review of Shortage of Skilled Craftsmen in Small and Medium Construction Firms in Nigeria, Journal of Environment and Earth Science 5(15), 98-110

Bustani, S.A. (2000). Availability and Quality of Construction Craftsmen and Artisans in the Nigerian Construction Industry. Journal of Construction Technology and Management, 3(1), 91-103.

Carley, L.A., Goodrum, P.M., Haas, C.T. and Borcherding, J.D. (2003). Experiences with multiskilling among non-unit craft workers in US industrial construction projects. Engineering, Construction and Architectural Management, 10 (6), 374-381.

Cohen, A. (2003). Multiple commitments in the workplace: An integrative approach. Mahwah, NJ: Lawrence Erlbaum

Ellemmer, N., Gilder, D., and Heuvel, H. (1998). Career oriented versus team-oriented commitment and behaviour at work. Journal of Applied Psychology 83 (3), 717-730

Gangai, K. N. and Agrawal, R. (2015). Job satisfaction and organisational commitment: is it important for employee performance. Int. J. Manag. Bus. Res., 5 (4), 269-278

Ghasemi, A. and Zahediasl, S. (2012). Normality Test for Statistical Analysis: A guide for non-statisticians. International Journal of Endocrinol Metab, 10 (2), 486489

Girth, H, Sertyesilisik, B, and Horman, B. (2013). An investigation into job Satisfaction and organisational commitment of construction personnel, Global Advanced Research Journal of Social Science, 2 (1), 1-11

Haq, M. A, Jindong, Y., Hussain, N. and Anjum, Z. Z (2014) Factors affecting organisational commitment among bank officers in Pakistan, IOSR Journal of Business and Management, 16 (4), 18-24

Ibrahim, A. R., Roy, M. H., Amed, Z., and Imtiaz, G., (2010), An investigation of the status of the Malaysian construction industry, Benchmarking: An International Journal, 17(2), 294-308

Institute Of Management and Administration (IOMA) (2005). Confronting the craft labour shortage. Contractor's Business Management Report, 1-7.

Irving, P.G., Coleman, D.F., and Cooper, C.L. (1997). Further assessment of a three-component model of occupational commitment: Generalizability and differences across occupations. Journal of Applied Psychology 82, 444-452.

Jena, R.K (2015). An assessment of demographic factors affecting organisational commitment among shift workers in India. Management, 20(1), 59-77

Luchak, A. A., Pohler, D. M. and Gellatly, I. R. (2008). When do committed employees retire? The effects of organisational commitment on retirement plans under a defined-benefit pension plan. Human Resource Management, 47 (3), 581-599.

Lumley, E. J., Coetzee, M., Tladinyane, R. and Ferreira, N. (2011). Exploring the job satisfaction and organisational commitment of employees in the 
information technology environment. Southern African Business Review, 15(1), 100-118

Markovits, Y., Boer, D. and van Dick, R. (2013). Economic crisis and the employee: The effects of economic crisis on employee job satisfaction, commitment, and self-regulation. European Management Journal, 32, 413-422

Martin, A. and Root, G. (2008). Perceptions of organisational commitment, job satisfaction and turnover intentions in a post-merger South African tertiary institution. South African Journal of Industrial Psychology, 34(1), 23-31.

Mathieu, J., and Zajac, D. (1990). A review and metaanalysis of the antecedents, correlates and consequences of organisational commitment. Psychological Bulletin, 108(2), 171-194.

Medugu, N. I., Rafee Majid, M., Bustani, S. A., Bala, K., Abdullahi, U., and Mbamali, I. (2011). Craft Skills Availability in the Nigerian Construction Industry: Perception of Contractors and Consultants. Craft Skills Availability in the Nigerian Construction Industry: Perception of Contractors and Consultants. The IUP Journal of Infrastructure, 9(3), 63-73

Meyer, J. P. and Allen, N. J. (1984). Testing the 'sidebet theory' of organisational commitment: some methodological considerations. Journal of Applied Psychology, 69, 372-378

Meyer, J. P. and Allen, N. J. (1997). Commitment in the workplace: Towards a general model: A review of literature. Research papers management, 11(3) 299-326

Meyer, J. P., Allen, N. J. and Smith, C. A. (1993). Commitment to Organisations and Occupations: Extension and Test of a Three-Component Conceptualization. Journal of Applied Psychology, 78 (4), 538-551

Miller, K. (2003). Values, attitudes and job satisfaction' In Robbins, S.P., Odendaal A. and Roodt, G. (Eds), Organisational Behavior: Global and Southern African Perspectives. Cape Town: Pearson Education South Africa.

Moser, C.A. and Kalton, G. (1999). Survey Methods in Social Investigation, 2nd Edition. Gower Publishing Company Ltd, Aldershot

Nagar, K. (2012). Organisational Commitment and Job Satisfaction among Teachers during Times of Burnout. Vikalpa, 37 (2), 43-60.

Nehmeh, R. (2009). What is Organizational commitment, why should managers want it in their workforce and is there any cost-effective way to secure it? SMC Working Paper, 5, 1-11

Norizan, I. (2012) Organisational commitment and job satisfaction among staff of higher learning education institutions in Kelantan, Doctoral Dissertation, University Utara Malaysia), 1-73

Odediran, S. J, Adeyinka, B. F, Opatunji, O. A. and Morakinyo, K. O. (2012). Business Structure of Indigenous Firms in the Nigerian Construction Industry. International Journal of Business Research and Management, 3(5), 255-264

Ogbu, C. P (2017). Survival practices of indigenous construction firms in Nigeria. International Journal of Construction Management, 18(1), 78-91

Olofinji, L. (2016). Why is there a shortage of Skilled Construction Workers in Nigeria. An article in the Nigeria Real Estate Hub. Accessible on: http://nigeriarealestatehub.com/shortage-skilledconstruction-workers-nigeria.html/

Olomolaiye, P.O and Ogunlana, S.O. (1989). An Evaluation of Production Outputs of Key Building Trades in Nigeria, Construction Management and Economics, 7(1), 75-86

Owoyemi, O. A., Oyelere, M., Elegbede, T., and Gbajumo-Sheriff, M (2011). Enhancing employees' commitment through training. International Journal of Business and Management, 6(7), 280-286.

Oyewobi, L.O., Bolaji, S., and Muhammad-Jamil, A. (2012). Job satisfaction and job commitment; A study of Quantity Surveyors in Nigeria Public service. International Journal of Business Management, 7 (5), 179-192

Pallant, J. (2005), SPSS Survival Manual: A Step by Step Guide to Data Analysis Using SPSS for Windows (Version 12). 2nd Edition, Allen and Unwin, Crow's Nest NSW 2065 Australia

Salim, M., Kamarudin, H. and Abdul-Kadir, M. B (2007). Factors affecting organisational commitment among lecturers in higher educational institution in Malaysia, Retrieved from http://elibrary.unw.ac.id/images/jurnal/4e5e0cd9c876e8652f3e7 ad21908b474.pdf

Spector, P. 2008. Industrial and Organisational Behaviour (5th edition). New Jersey: John Wiley and Sons.

Tan, W.C.K. (2011), Practical Research Methods, Pearson Custom: Singapore.

Tucker, R. L., Haas, C. T., Glover, R. W., Alemany, C. H., Carley, L. A., Eickmann, J. A., Rodriguz, A. M. and Shields, D. (1999). Craft Workers' Experiences with and attitudes Towards Multiskilling. Report No. 3, Center for Construction Industry Studies, The University of Texas at Austin, Austin, TX.

Ugheru, D.C. (2006). Training of craftsmen for Nigeria construction industry. Journal of the Nigerian Association of Engineering Craftsmen, 5, 9-10. 